\title{
An Experimental Study on Cement Concrete with Partial Replacement of Cement Using Marble Dust Powder
}

\author{
P. Senthamilselvi ${ }^{1}$ \\ Assistant Professor, \\ Department of Civil Engineering, \\ Government College of Engineering, \\ Salem-11,Tamil Nadu ,India.
}

\begin{abstract}
The waste generated from the industries motive environmental issues. For this reason the reuse of these wastes are often emphasised.Thus Marble dust powder (MDP) is one of the fast growing waste material which can be used in the concrete production industry to minimize material use and produce financial advantage. In this study, the marble dust powder passing through 90 micron sieve, has been utilized for determining the hardened properties of concrete .The hardened properties of concrete has been determined with the effect of different rate replacement of cement by MDP.In this examination work, MDP has replaced the Ordinary Portland Cement (OPC) at an increasing rate from $0 \%$ to $20 \%$ by weight in $M_{30}$ grade concrete. The motivation behind this investigation is to examine the behavior of concrete with the substitution of cement by MDP in various extents in concrete.
\end{abstract}

Keywords:- Cement, concrete, compressive strength, flexure strength, marble dust powder, split-tensile strength.

\section{INTRODUCTION}

Marble is obtained as the result of transformation of natural limestone. It is durable in characteristics and is used for construction and decoration purposes. During the cutting process, an enormous amount of marble dust powder are produced which causes ecological issues when it is exposed to the surrounding. Also the porosity and penetrability of topsoil reduces by means of deposition of MDP on the soil and it reduces the fertility of the soil by means of increasing alkalinity. Moreover, there will be only minimum amount of materials available for the production of cement. In order to overcome this problem MDP can be used as partial alternative of cement for casting of concrete.

Also these marble dust powder are utilised in various commercial sectors which assist to shield the environment. In recent times, concrete has a tremendous advancement in concrete technology wherein it may lessen the intake of natural assets as well as the energy sources and which can

\author{
A.Amrish $^{2}$, K.S.Aravind ${ }^{3}$, S.Elansezhiyan ${ }^{4}$, A.Jeyashri ${ }^{5}$ \\ Final year students \\ Department of Civil Engineering, \\ Government College of Engineering, \\ Salem-11,Tamil Nadu, India.
}

further reduce the effect of pollution on the surroundings. This project deals with the casting of the concrete with varying proportion of MDP and then analyzing the test results.

\section{OBJECTIVE}

To determine the effect of concrete with partially replacing cement with marble dust powder and finding the properties of hardened concrete such as compressive strength,split tensile strength and flexural strength and compared it with the normal concrete.

\section{LITERATURE REVIEW}

Manju Pawar , Arvind Dewagan (2014) examined the marble dust powder (pozzolanic material) for cement in high strength concrete. The hardened properties of concrete increases with increase in MDP content up to $12.5 \%$ replacement by weight of cement and above that an increase in MDP content decreases the strength properties of concrete. Thus the result of the study shows that the strength properties of concrete has been improved by incorporating MDP to a desirable content of $12.5 \%$ by weight ofcement.

V.M. Sounthararajan , A.Sivakumar (2013) examined the effect of lime content in MDP on concrete properties.Thus this paper reports that the mechanical property of concrete increased compared to controlled concrete upto $10 \%$ replacement of MDP in cement content.

Baboo Rai,Khan Naushad, Abhishek, Tabin Rushad, Duggal.S.K. in 2011examined the result of high strength concrete using marble dust powder in concrete.In this study, cement and fine aggregate are partially replaced and examined the workability and hardened properties of concrete.Thus these replacement reveals that increase in MDP content results in increased workability and compressive strengths of concrete. 


\section{EXPERIMENTAL DETAILS}

In this experiment, concrete (Grade $\left.\mathrm{M}_{30}\right)$ were casted with appropriate replacement of cement by MDP upto $20 \%$ and properties were determined.In this assessment, physical properties of materials utilized were deteremined.
A. Properties of the Materials:

The physical properties of the materials utilized in the casting of concrete and the chemical compositions of the marble powder and cement utilized are shown in table 1,2 respectively.

\begin{tabular}{|c|c|c|c|c|}
\hline Properties & $\begin{array}{c}\text { Cement } \\
\text { (OPC) }\end{array}$ & $\begin{array}{c}\text { Marble dust } \\
\text { powder }\end{array}$ & $\begin{array}{c}\text { Fine aggregate } \\
\text { (M-sand) }\end{array}$ & $\begin{array}{c}\text { Coarse aggregate } \\
\text { (Size 10mm to 20mm) }\end{array}$ \\
\hline Fineness & $4 \%$ & $15 \%$ & $-2.2 \%$ & - \\
\hline Normal consistency & $30 \%$ & $30 \%$ & 2.85 & - \\
\hline Specific gravity & 3.15 & 2.63 & - & - \\
\hline Initial Setting time & $85 \mathrm{mins}$ & $135 \mathrm{mins}$ & - & $19.69 \%$ \\
\hline Impact strength & - & - & - & $18.3 \%$ \\
\hline Crushing strength & - & - & - & \\
\hline
\end{tabular}

Table 1:- Physical properties of Cement, Fine aggregate, Coarse aggregate, Marble dust powder.

\begin{tabular}{|c|c|c|}
\hline Oxide compounds & \multicolumn{2}{|c|}{$(\%)$} \\
\cline { 2 - 3 } & Marble dust powder & 57.02 \\
\hline Calcium oxide $(\mathrm{CaO})$ & 42.45 & 2.59 \\
\hline Aluminumdioxide $(\mathrm{Al} 2 \mathrm{O} 3)$ & 0.52 & 21.77 \\
\hline Silica dioxide $(\mathrm{SiO} 2)$ & 26.35 & 0.65 \\
\hline Iron oxide $(\mathrm{Fe} 2 \mathrm{O} 3)$ & 9.40 & 2.71 \\
\hline Magnesium oxide $(\mathrm{MgO})$ & 1.52 & \\
\hline
\end{tabular}

Table 2:- Chemical composition of MDP and OPC(53grade).

\section{B. Concrete Mix Constituents:}

The materials used for manufacturing of concrete are shown in figure 1. (a),(b),(c),(d). The materials are mixed in the pan mixture as shown in figure 2 for making concrete.
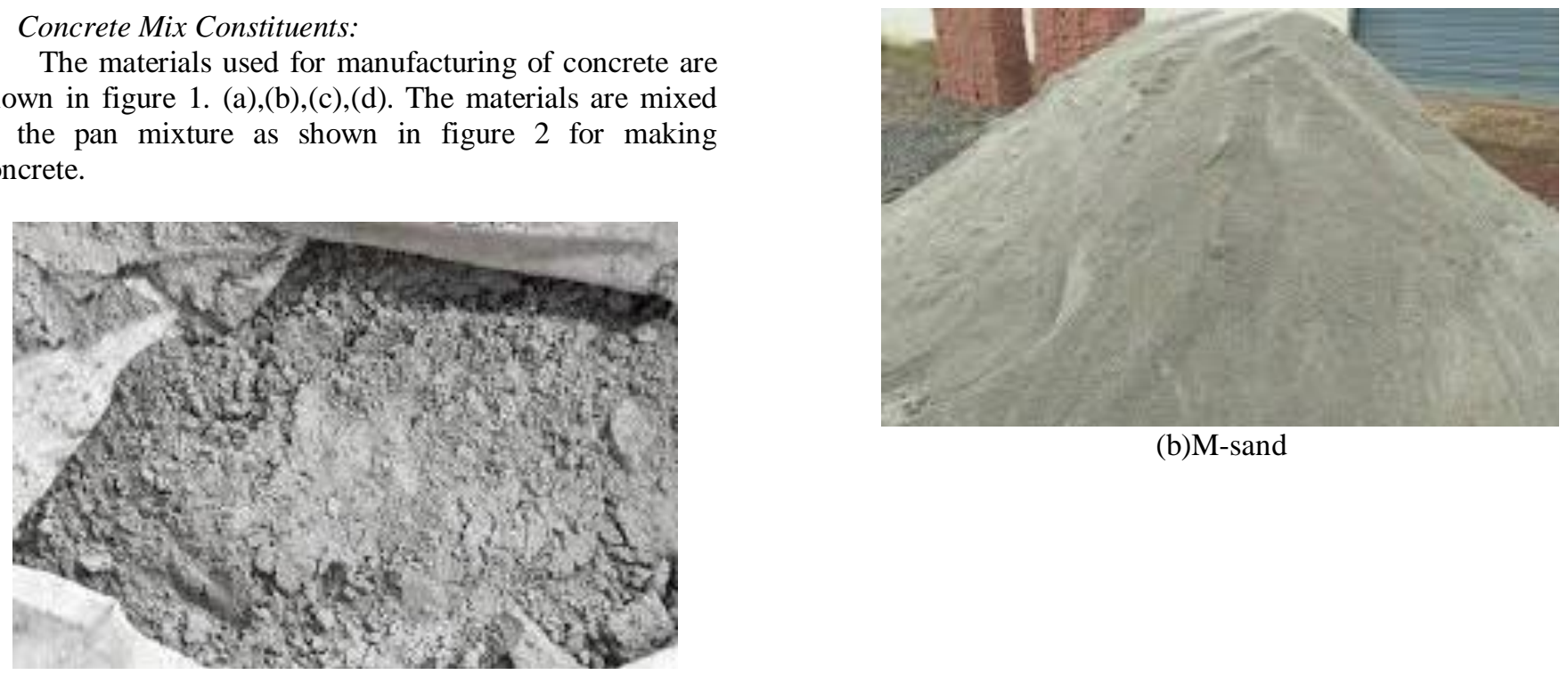

(a) Cement 


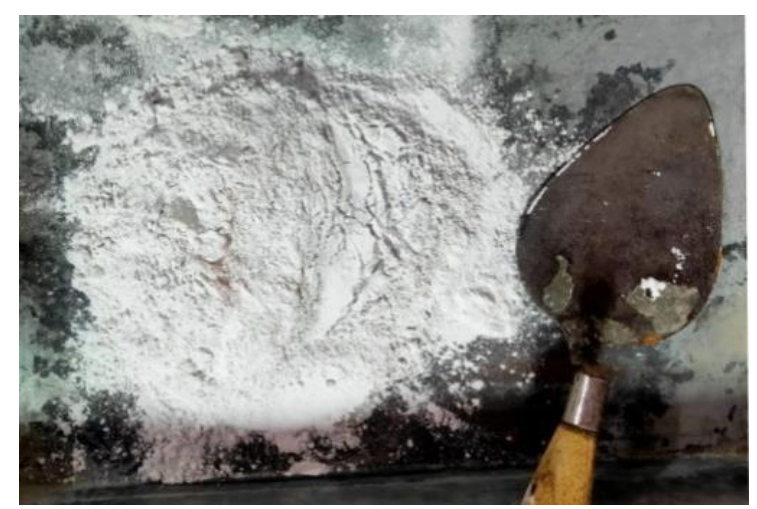

(c)Marble dust powder

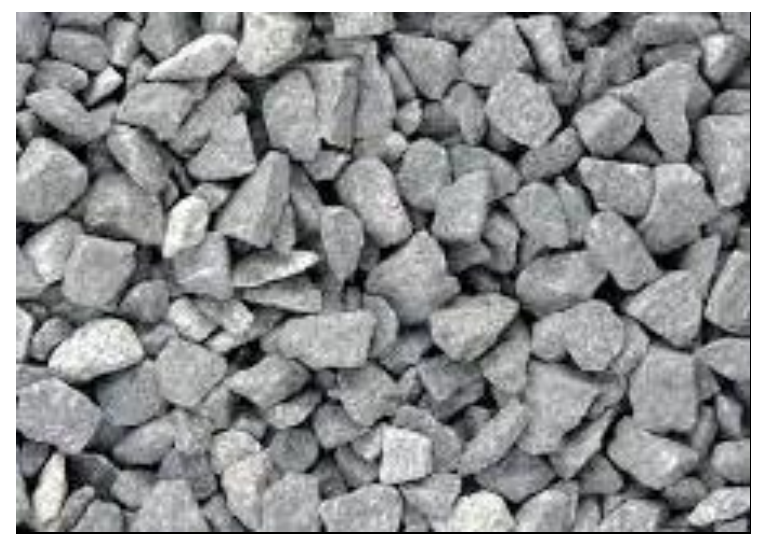

(d)Coarse aggregate

Fig 1:- Materials used in the study

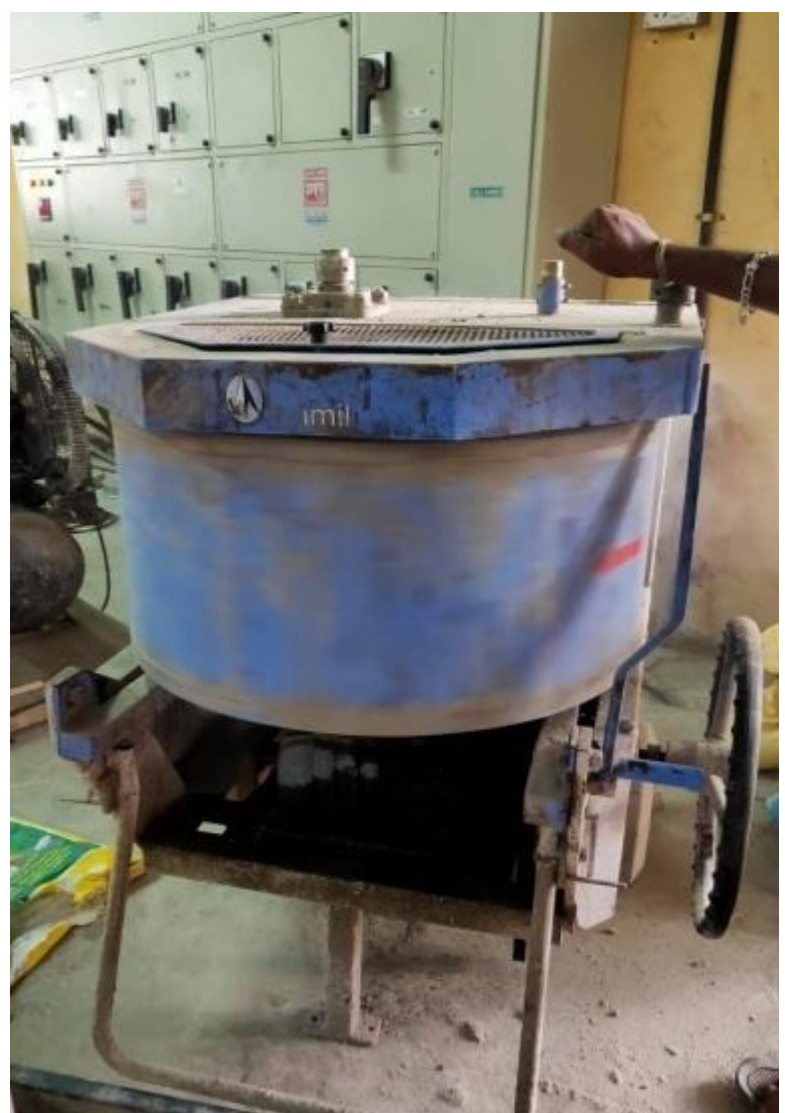

Fig 2:- Mixing process in standard pan type mixer.

\section{EVALUATION OF STRENGTH PROPERTIES}

The quality of concrete depends upon the strength property of hardened concrete.Because of this importance,several tests has been conducted and their test results are reported as follows.

\section{A. Compressive Strength Test:}

For this test $100 \mathrm{mmX} 100 \mathrm{mmX} 100 \mathrm{~mm}$ sized concrete cubes are used The test is conducted on compressive testing machine. Mechanical behavior of concrete was studied for $\mathrm{M}_{30}$ grade concrete. At various proportions of marble dust powder,concrete cubes were casted and used for testing.Atlast cubes were tested and the outcomes acquired are shown below(In table $3 \&$ graph 1).

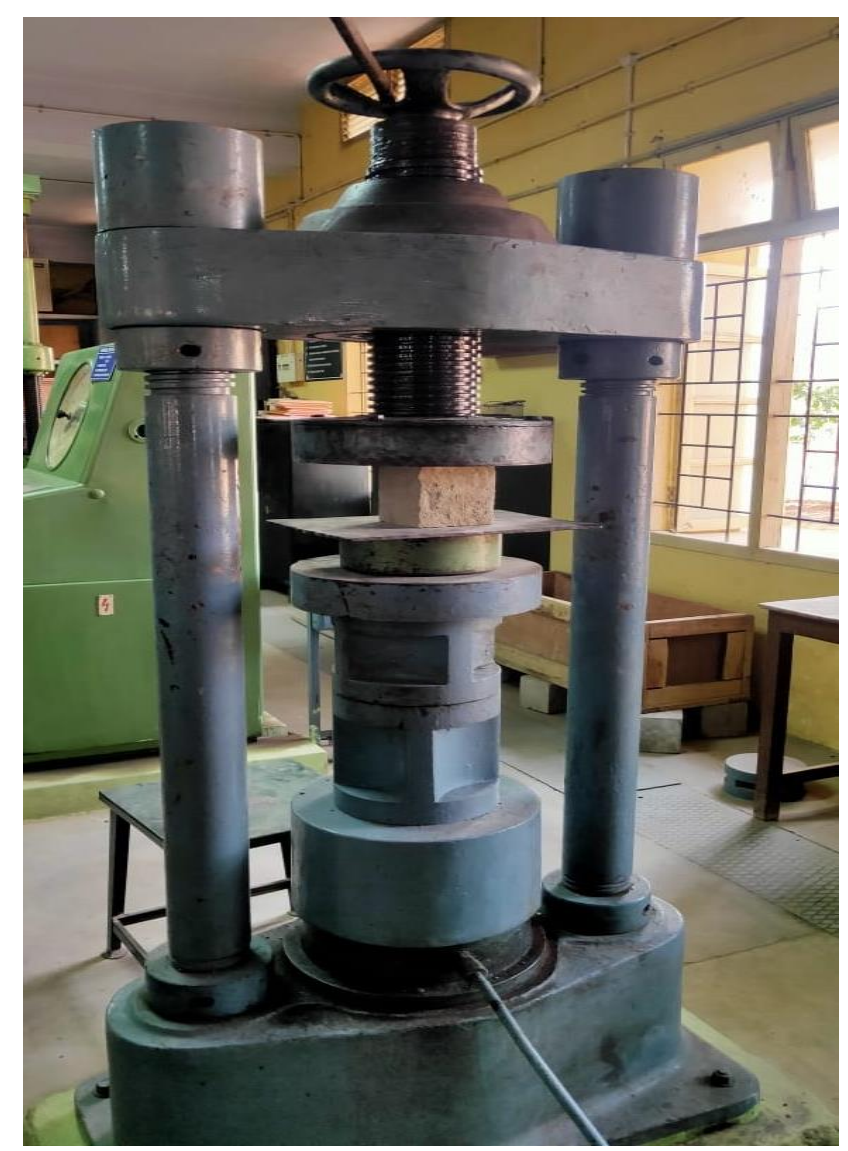

Fig 3:- Experimental setup for compressive strength

\begin{tabular}{|c|c|c|c|}
\hline \multirow{2}{*}{$\begin{array}{c}\text { \% Replacement of } \\
\text { MDP to cement }\end{array}$} & \multicolumn{3}{|c|}{$\begin{array}{c}\text { Compressive strength in } \\
\text { N/mm }\end{array}$} \\
\cline { 2 - 4 } & $\mathbf{7 ~ d a y s}$ & $\mathbf{1 4}$ days & 28days \\
\hline 0 & 47.08 & 48.06 & 51.012 \\
\hline 5 & 27.46 & 42.18 & 44.145 \\
\hline 10 & 26.48 & 40.22 & 41.202 \\
\hline 15 & 20.6 & 38.25 & 40.22 \\
\hline 20 & 15.69 & 34.33 & 37.278 \\
\hline
\end{tabular}

Table 3:- Analysis of test results 


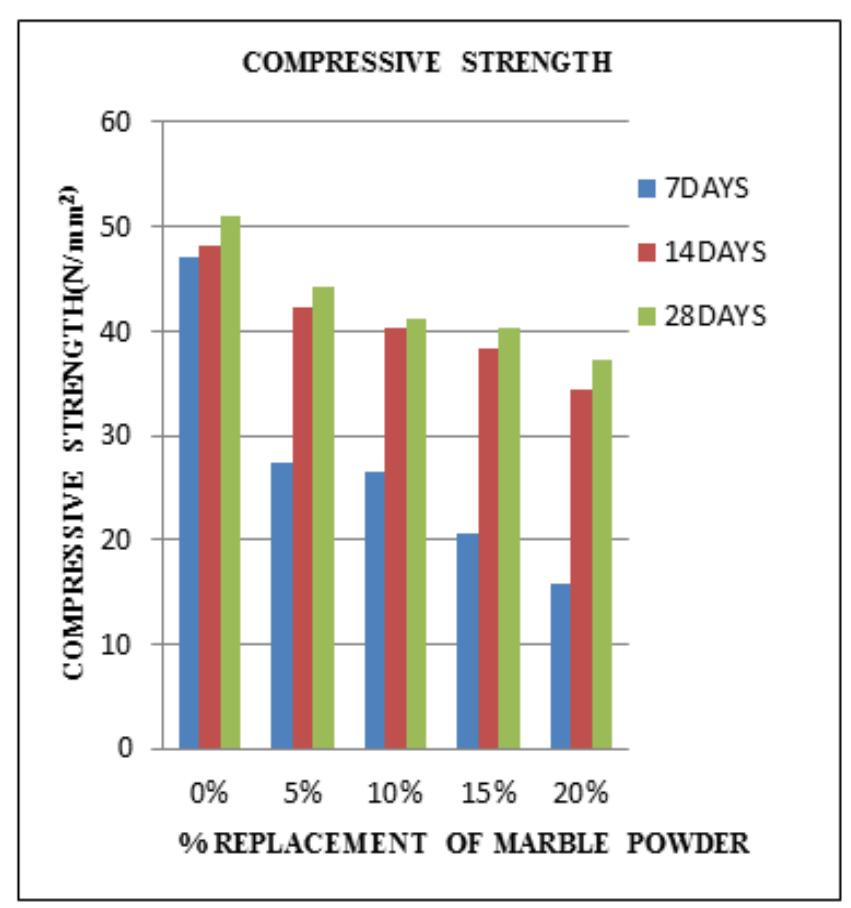

Graph 1

B. Split Tensile Strength Test:

For this test $100 \mathrm{~mm} \times 200 \mathrm{~mm}$ sized concrete cylinders are used. Load is applied over the surface of concrete cylinder till the failure takes place.Compression testing machine was used for this test.The cylinder is located horizontally and cylinder packing material is used to overcome sudden loading. The formula utilized for this test is,

$\mathrm{T}=2 \mathrm{P} / \pi \mathrm{DL}$

Where,

$\mathrm{T}=$ Tensile Strength,

$\mathrm{P}=$ Load at which cylinder fails in $\mathrm{N}$,

$\mathrm{L}=$ Length of cylinder,

$\mathrm{D}=$ Diameter of cylinder.

Thus the cylinders were tested and the outcomes acquired are shown below (In table $4 \&$ graph 2 ).

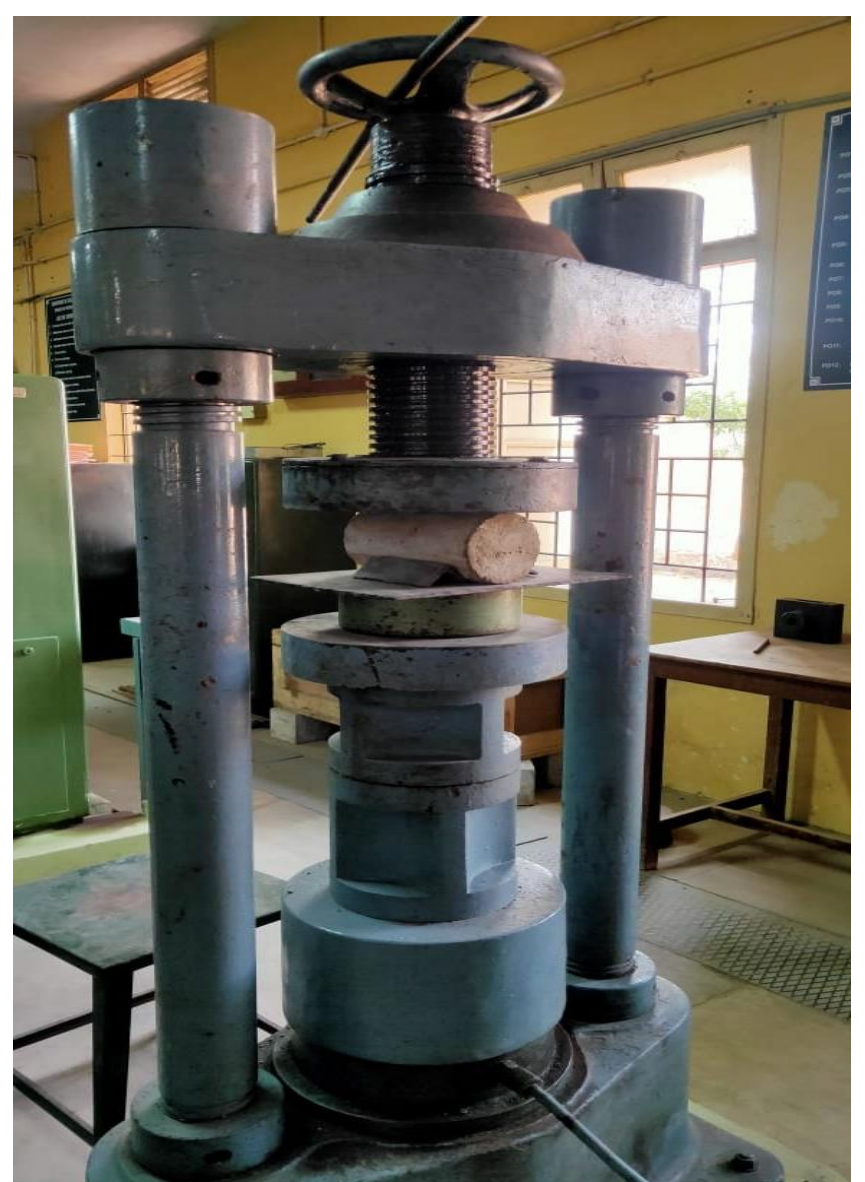

Fig 4:- Experimental setup for split tensile strength

\begin{tabular}{|c|c|c|}
\hline \multirow{2}{*}{$\begin{array}{c}\text { \% Replacement of } \\
\text { MDP to cement }\end{array}$} & \multicolumn{2}{|c|}{ Split tensile strength in N/mm } \\
\cline { 2 - 3 } & 14 days & $\mathbf{2 8}$ days \\
\hline 0 & 4.05 & 4.99 \\
\hline 5 & 3.74 & 4.37 \\
\hline 10 & 3.12 & 4.05 \\
\hline 15 & 2.81 & 3.74 \\
\hline 20 & 2.49 & 3.12 \\
\hline
\end{tabular}

Table 4:- Analysis of test results 


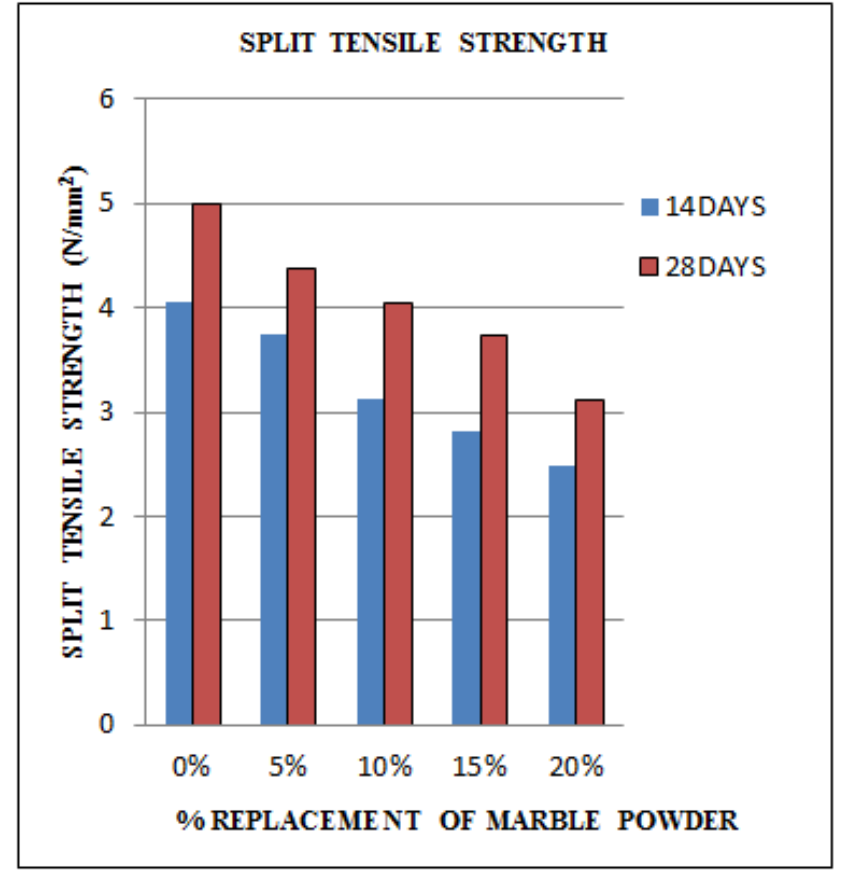

Graph 2

\section{Flexural Strength:}

For this test $500 \mathrm{mmX} 100 \mathrm{mmX} 100 \mathrm{~mm}$ sized concrete prisms were used. Universal testing machine was used for finding the flexure .The surface of the prisms were cleaned before loading the machine. The prisms are placed in such a way that the axis of the prism lined up with the testing machine.Then the load is applied along the upper most surface.

Flexural strength, $\left(\mathrm{N} / \mathrm{mm}^{2}\right)=\mathrm{PL} / \mathrm{bd}^{2}$

Where,

$\mathrm{P}=$ Load at which prism fails in $\mathrm{N}$,

$\mathrm{L}=$ Length of prism,

$\mathrm{b}=$ Width of prism in $\mathrm{mm}$,

$\mathrm{d}=$ Depth of prism in $\mathrm{mm}$.

Then, the prisms were tested and the outcomes acquired are shown below (In table $5 \&$ graph 3 ).

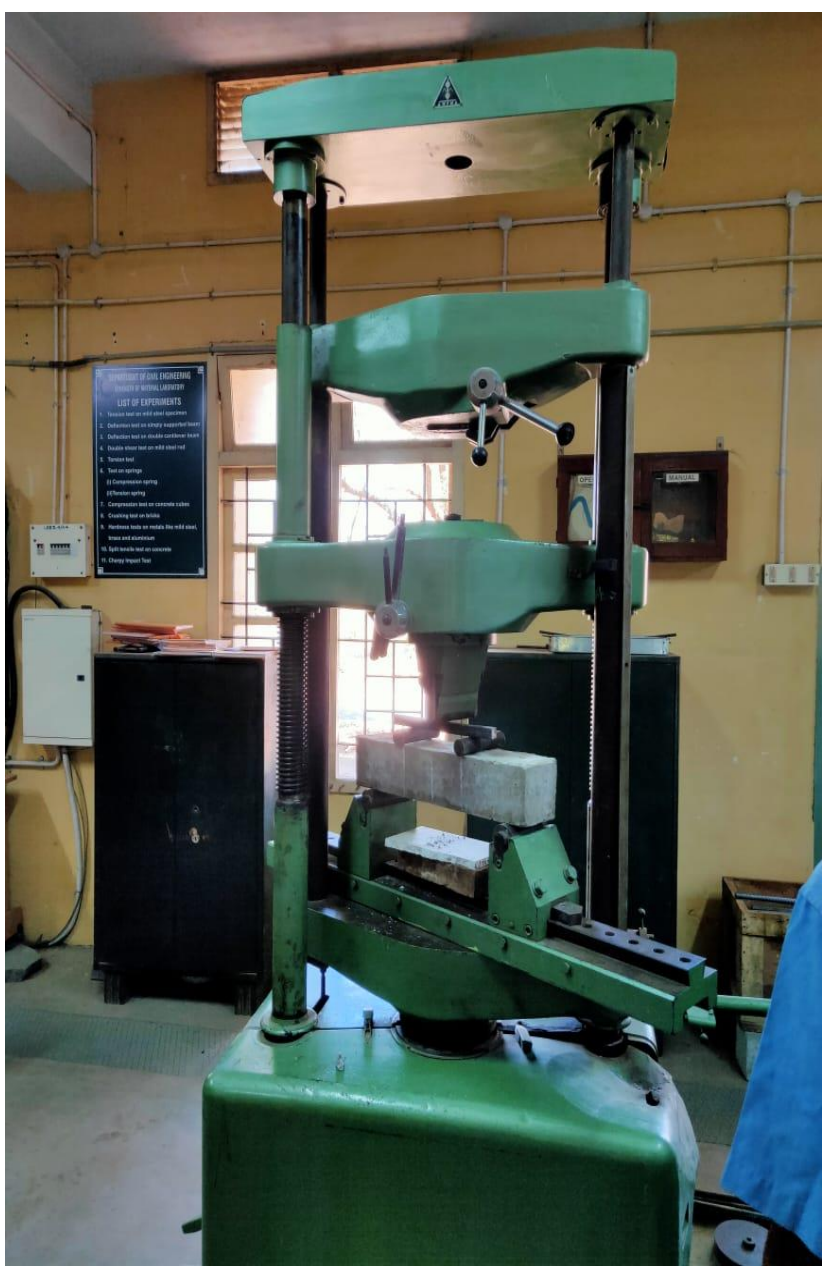

Fig 5:- Experimental setup for flexural strength test.

\begin{tabular}{|c|c|}
\hline $\begin{array}{c}\text { \% Replacement of MDP } \\
\text { to cement }\end{array}$ & $\begin{array}{c}\text { 28 days flexural strength in } \\
\mathbf{N} / \mathbf{m m}^{\mathbf{2}}\end{array}$ \\
\hline 0 & 11.18 \\
\hline 5 & 8.73 \\
\hline 10 & 7.65 \\
\hline 15 & 7.16 \\
\hline 20 & 6.18 \\
\hline
\end{tabular}

Table 5:- Analysis of test results 


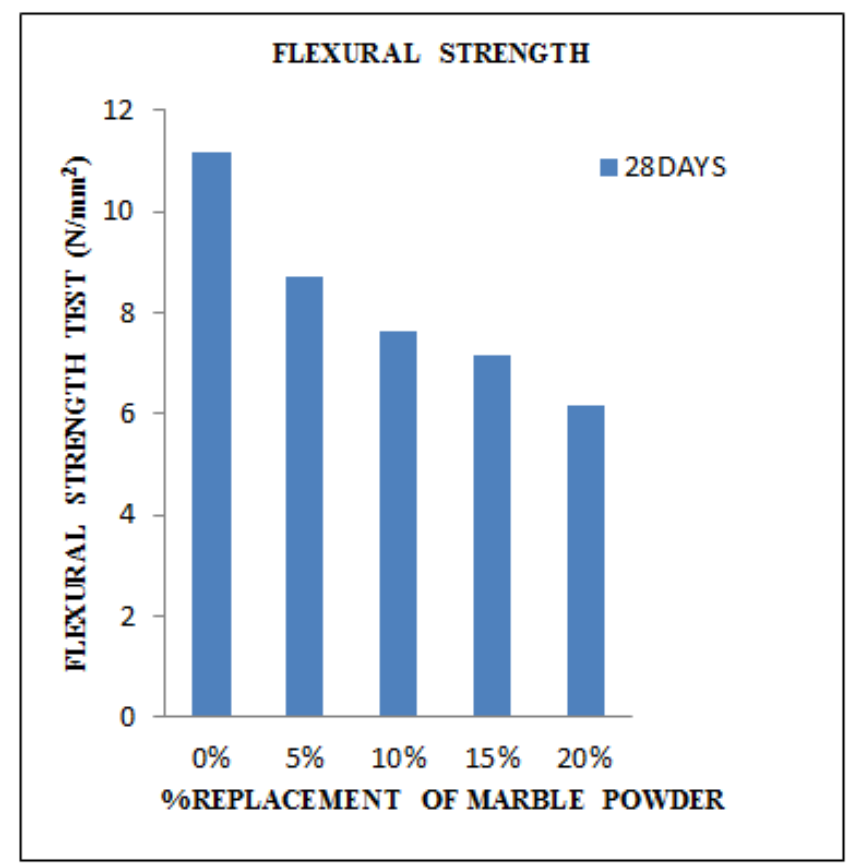

Graph 3

\section{CONCLUSION}

Due to the excessive fineness of marble dust powder the pores in the concrete increases, which causes decline in compressive strength, split tensile strength and flexural strength of concrete with increase in marble dust powder content.

Upto $20 \%$ replacement of cement by MDP the strength of concrete although gets decreased it does not reduce the strength below the design strength of concrete i.e. $\mathrm{M}_{30}$

$>$ As the target strength of $\mathrm{M}_{30}$ grade concrete is about $38.25 \mathrm{MPa}$ it is recommended to replace the cement by MDP for about $5 \%$.

Use of this MDP causes economical development in construction industry.

\section{REFERENCES}

[1]. Mr. Ranjankumar, Shyamkishorkumar in 2015 examined a review on replacement of cement by marble dust powde.International Journal of engineering research and applications, ISSN:22489622,Vol. 5,Issue 8,(Part-4) August 2015.

[2]. Vijaya Kumar,Shruti,Tharan,Sanjay,Sricharan by imparting marble dust powder in concrete. IJMTST Journal,ISSN:2455-3778, Vol. 2,Issue 05,May 2016.

[3]. Jashandeepsingh, R.S. Bansal, examined the effect of marble dust powder in $\mathbf{M}_{25}$ grade of concrete. International Journal of Technical Research and Applications, Volume 3, 2015.

[4]. Gopi.R ,Kaleeswari. G, Dhanalakshmi .G examined the effect of inclusion of marble powder as partial replacement of cement in concrete.GRD Journal,ISSN:2455-5703, Volume 2 ， Issue 7,June 2017 . 